\title{
Periodismo de catástrofes: el 11 de septiembre. Análisis del suceso y experiencias vividas
}

\author{
Rosa Rodríguez Cárcela \\ Periodista, miembro del Grupo de Investigación en Estructura, Historia y \\ Contenidos de la Comunicación \\ M. Ángeles Martín Ruiz \\ Licenciada en Ciencias de la Información, Universidad de Sevilla
}

\section{RESUMEN}

Esta investigación se divide en dos partes diferenciadas. Una primera dedicada al análisis del periodismo de catástrofes: características y tratamiento, extrapolado a los actos terroristas del 11 de septiembre de 2001. En la segunda parte, se cuentan las experiencias vividas, en el centro de Nueva York, de una periodista sevillana que estuvo el mismo día del atentado y cubrió la noticia. En los anexos se incluyen copias de las portadas que publicaron los diarios $\mathrm{ABC}, \mathrm{El}$ Mundo y El País el día siguiente, así como un reportaje publicado en el Diario de Sevilla, con motivo del primer aniversario del 11-S y una entrevista en exclusiva con el doctor Manuel Trujillo, director de Psiquiatría del Centro Hospitalario Bellevue de Nueva York.

\section{ABSTRACT}

This investigation is divided in two parts. One is dedicated to catastrophe journalism analysis: characteristics and treatment related to the September $11^{\text {th }}$ terrorist attacks. The second part narrates the experiences lived by a journalist from Sevilla covering the news from the center of $N Y$ the day of the attacks. In the attached annexes there are front cover copies for the " $A B C$ ", "El Mundo" and "El Pais" daily journals the day after the attacks. There is also an article published in "El Diario de Sevilla" to commemorate the first anniversary of the 9-11 attacks and one exclusive interview with Doctor Manuel Trujillo, director of the Mental institute in the Bellevue Hospital Center of New York.

Palabras claves: Periodismo de catástrofes/Terrorismo/Atentado 11 de septiembre/Nueva York.

Key words: Catastrophe journalism/Terrorism/9-11 Attack/New York.

\section{1 a PARTE: \\ PERIODISMO DE CATÁSTROFES \\ Rosa Rodríguez Cárcela}

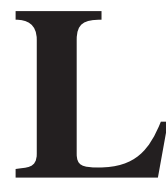

as informaciones sobre catástrofes publicadas en los medios de comunicación son siempre espectaculares, debido al elevado número de víctimas que causan y los daños materiales que provocan. Las catástrofes podemos dividirlas entre aquellas de origen natural, generadas por fuer- 
zas de la naturaleza, como los terremotos, lluvias torrenciales, huracanes, maremotos o erupciones volcánicas; y las provocadas por la acción del ser humano, como los incendios forestales, los atentados al medio ambiente, las contaminaciones masivas y, sin duda, los grandes atentados terroristas.

La Asociación Española de Lucha contra el Fuego (ASELF) también establece una clasificación parecida al diferenciar entre catástrofes masivas de origen natural, como un terremoto; o provocadas, como un atentado terrorista ${ }^{1}$.

Los actos de terrorismo masivo tienen resultados catastróficos por los múltiples muertos y heridos que se producen, así como por las destrucciones de bienes inmuebles y muebles que tienen lugar. Sin olvidar el hecho del impacto social, psicológico, económico y político que ocasionan. En cualquier caso se trata de sucesos que originan verdaderas tragedias y tienen un gran impacto en los medios de comunicación.

A veces se producen hechos catastróficos que, por su carácter excepcional, se imponen a los condicionamientos informativos y periodísticos, acaparando los lugares más destacados del periódico o de cualquier otro medio de comunicación. Manuel Bernal los denomina «hechos-ruptura ${ }^{2}$, caracterizados por su gravedad y centralidad.

Para Lorenzo Gomis un grupo especial de estos hechos-ruptura son las «explosiones», cuya importancia se mide por el número de muertos. Estos acontecimientos se convierten en portada por sí mismos, ya que la sociedad entera se moviliza y los propios medios actúan como agentes «profesionalmente interesados». Las personas se preguntan cuáles son sus posibles repercusiones, una vez que se han producido. Por este motivo, Gomis, considera que ocupan los primeros puestos de la atención informativa ${ }^{3}$.

Se trata, como los atentados de las Torres Gemelas de Nueva York y contra el Pentágono en Washington cometidos el 11 de septiembre de 2001, de noticias excepcionales e imprevisibles que se imponen a la «compleja burocracia informativa», como indica Grossi ${ }^{4}$. Pero además conviene decir, tomando como referencia a Rodrigo Alsina, que el carácter excepcional de un acontecimiento se define también en función de las convenciones sociales vigentes en cada lugar y momento $^{5}$. Es decir, que el acto terrorista conocido mundialmente como $11-S$, hay que

1 «España, 'desprotegida' contra las catástrofes», noticia publicada en Diario 16 Andalucía, 27 de abril de 1995, pág. 12.

2 BERNAL RODRÍGUEZ, Manuel: «La construcción social de la realidad en los titulares de prensa» en AA.VV., Andalucía como ámbito de interés periodístico. Padilla Libros Editores\&Libreros, Serie Comunicación, Sevilla, 1998, pág. 71.

3 GOMIS, Lorenzo: Teoría del periodismo. Cómo se forma el presente. Paidós, Barcelona, 1991, págs. 143148 .

4 Véase RODRIGO ALSINA, M.: La construcción de la noticia. Barcelona, 1993, pág. 108.

5 RODRIGO ALSINA, M.: Op. cit., pág. 108 
situarlo en un conjunto de circunstancias sociales, ideológicas y culturales que contribuyeron a potenciar su impacto. En este aspecto abundaremos posteriormente, al analizar las portadas de tres diarios nacionales de gran tirada.

Que los actos de 11 de septiembre de 2001 no fueron una catástrofe natural es evidente, pero sus efectos y consecuencias han sido como los de un gran terremoto en las mismas entrañas, en el centro neurálgico, de la primera potencia mundial. A primera vista se puede considerar como una gran catástrofe provocada por un grupo terrorista islámico perfectamente organizado. Ya veremos que se trata de algo más, desde el punto de vista de la información, la comunicación y en general de las relaciones internacionales.

Ha sido una gran catástrofe provocada que posee unas características que la convierten en un suceso periodístico de primera magnitud; no sólo por el lugar emblemático donde se produce y el numeroso porcentaje de víctimas, sino por las implicaciones políticas, sociales y económicas que tiene. Uno de los elementos más impactantes visualmente de este suceso catastrófico fueron las explosiones que provocaron el choque de los dos aviones contra las citadas torres gemelas. Ese momento ha sido una imagen reiteradamente televisada en todas las cadenas del mundo y publicada en las primeras páginas de los diarios más importantes. Fue un suceso repentino y alarmante, propio de las grandes catástrofes. En este sentido, Gomis matiza que las explosiones «son el término imprevisto de procesos inesperados» y representan la irrupción de la alarma en la sociedad ${ }^{6}$.

Otro elemento que no conviene nunca olvidar, y que es consustancial del periodismo de catástrofes, es el elevadísimo número de víctimas que provoca y que en el caso de actos terroristas se le denominan masacres. En este caso, el término no se equipara con una mortandad fortuita o catástrofe natural, sino que, tal y como recoge el Diccionario de la Real Academia Española (DRAE), sólo cabe hablar de masacre en situaciones de matanza de personas por ataque armado o causa semejante. Y puntualiza sobre las víctimas: «por lo general indefensas» ${ }^{7}$. Esta matización académica encaja perfectamente en la consideración de la masacre provocada el 11$S$. Fue un ataque premeditado y realizado sobre personas indefensas, sin ninguna opción para defenderse frente a sus verdugos, los cuales, paradójicamente, también se convirtieron voluntariamente en víctimas al actuar como camicaces.

El Mundo, en un editorial publicado un año después del atentado, expresa su opinión sobre cómo esta masacre ha cambiado la concepción del mundo: «El 11 de septiembre marca una nítida frontera entre el pasado y el futuro, de suerte que no es exagerado decir que la masacre de Nueva York es el último acontecimiento del siglo XX y el primero de una época cuyos perfiles son todavía poco nítidos» ${ }^{8}$.

6 GOMIS, Lorenzo: Op. Cit., pág. 200.

7 Véase MUÑOZ, José Javier Muñoz: Diccionario de Periodismo. Librería Cervantes, Salamanca, 2000, pág 137.

8 «Un mundo en el que la libertad está más amenazada y peor defendida», El Mundo, 11-09-02, pág. 3. 
Periodismo de catástrofes: el 11 de septiembre. Análisis del suceso y experiencias vividas

\section{Características periodismo de catástrofes:}

En opinión de los periodistas Sibila Camps y Luis Pazos, las noticias de siniestros y catástrofes en general se sitúan entre las más complejas del trabajo periodístico, debido a varios motivos: "Con frecuencia repercute en varios planos de la vida de una comunidad y hasta de un país (social, sanitario, económico, político). La emergencia se prolonga y va modificándose a lo largo de varios días. Lo dramático de las circunstancias implica situaciones de caos, urgencia y estrés para los afectados y para quienes intervienen en las tareas de auxilio, y por lo tanto, también para el periodista".

El 11-S ha sido un hecho excepcional, provocado por un grupo terrorista que, debido a las dimensiones del desastre, del lugar y de la importancia de las consecuencias, ha despertado un interés periodístico y social que ha quedado marcado como uno de los hechos más relevantes después de la II Guerra Mundial, como así lo han reconocido numerosos articulistas, periodistas y directores de periódicos.

Las catástrofes naturales ocasionan, especialmente en países en vías de desarrollo, gran número de víctimas y daños, que son objeto de las primeras páginas de los periódicos. Son los terremotos, huracanes e inundaciones los tres sucesos más graves referidos a este tipo de noticias, sobre todo por el elevado número de fallecidos, los efectos causados por los desastres y la movilización nacional e internacional de ayuda civil que suponen.

Como dato a tener en cuenta hay que señalar que entre las catástrofes naturales más graves acontecidas a finales del siglo XX sobresalen, entre otras, el terremoto de Afganistán (9.100 muertes), el huracán Mitch en Centroamérica (9.200), el huracán George en el Caribe y EE.UU. (más de 4.000); o las inundaciones en Bangladesh, India y Nepal, con un balance de 4.759 muertos $^{10}$. Las estimaciones de muertos del $11-S$ sitúan la cifra en cerca de 3.000 personas. Concretamente, la Oficina del Jefe de Servicios Forenses de Nueva York sitúa el número en 2.823 fallecidos y se considera el recuento oficial más completo difundido hasta el momento ${ }^{11}$.

En estos casos, la información que se facilita sobre los muertos es relativa, ya que con frecuencia sólo es posible determinar el número de forma aproximada. No obstante, Camps y Pazos opinan que, aunque a veces la falta de datos se debe al caos producido por la catástrofe, cuando ocurre un siniestro de estas características es frecuente que, a causa de intereses políticos, la información sobre su

9 CAMPS, Sibila y PAZOS, Luis: Así se hace periodismo. Manual práctico del periodista gráfico. Paidós, Buenos Aires, 1996, pág. 181.

10 Diario de Sevilla: "Se triplican los muertos en España por catástrofes naturales", 16-10-99, sección Sociedad, pág. 23.

11 MARTÍN, M. Ángeles: «La vida se impone a la tragedia», en el suplemento especial 'El Día que cambió el mundo', Diario de Sevilla, 11-9-2002, pág. 2. 
magnitud sea ocultada o falseada. En opinión de los dos autores argentinos, esto suele suceder especialmente en lo referido al número de víctimas, a la eficacia de las tareas de auxilio, a las consecuencias económicas del desastre y a los pronósticos sobre evolución de la emergencia. En uno u otro caso, las dificultades para cubrir estos sucesos son casi siempre las mismas para el periodista, como ha ocurrido con el 11-S.

En cuanto al género narrativo de la catástrofe, se manifiesta un modo específico de hacer en donde los periódicos elaboran y muestran la tragedia y la muerte, con representaciones y manifestaciones de la sociedad y los gobiernos afectados. En este caso, el 11-S también reflejó en los medios de comunicación un modo de hacer periodístico marcado por la catástrofe. De este modo, se observa la aparición de elementos comunes en los medios de comunicación, especialmente en la prensa escrita y digital, así como en la televisión.

En primer lugar, hay que constatar la importancia de lo visual, de la fotografía y de la imagen en general en una distribución equilibrada con las portadas de la información textual y fotográfica, destacando lo gráfico frente a lo textual. La información básica se sintetiza a través de un título de catástrofe y una foto de grandes dimensiones, a manera de ventana o pantalla que abarca la mitad o la totalidad del espacio de la portada. La fotografía, en sí misma, funciona como noticia y testimonio para ver o mirar la magnitud del hecho y comprobar la veracidad de los hechos. Asimismo, actúa como ventana o portada de acceso al interior informativo de los diarios.

En segundo lugar se observa en las informaciones de catástrofes los titulares a grandes cuerpos, en negrita y muy gráficos, de estilo opinativo e interpretativo, frente al preponderante titular informativo. Se utilizan los títulos catástrofe («Más de 10.000 muertos"/ "Miles de víctimas..."). Es una narración abreviada de los hechos, pero muy gráfica y espectacular, de llamada al lector.

En tercer lugar, la terminología utilizada en la explicación de los hechos. Existe una preponderancia del campo semántico vinculado con la tragedia, consustanciales con los rasgos lingüísticos empleados en el género de catástrofes ("Desolador aspecto", "Alerta máxima", "Crisis", "Miles de muertos entre los escombros", Infamia", "Tragedia"...).

En cuanto a las fuentes empleadas en la elaboración del discurso periodístico referido a catástrofes, en este caso aplicado al $11-S$, se observa una preponderancia de fuentes de agencias extranjeras y de la CNN de EE.UU. Las fotografías provienen sobre todo de agencias extranjeras, mayoritariamente: Dpa, Ap, Epa, Reuters, NBC; o bien propias del diario (de archivo o de fotógrafos del periódico) y el recurso de la infografía.

Las informaciones periodísticas provienen de enviados especiales y de los cronistas que están en Washington o Nueva York, que recopilan las informaciones de la todopoderosa cadena CNN, así como de fuentes propias. Testigos de la calle, 
Periodismo de catástrofes: el 11 de septiembre. Análisis del suceso y experiencias vividas

teletipos, declaraciones de políticos y cuerpos de seguridad (bomberos, policías, etcétera), sin olvidar la radio como fuente casi instantánea.

En este tipo de situaciones extremas las fuentes utilizadas se basan tanto en las informaciones confidenciales, como en los rumores. Un buen ejemplo de ello lo plasma Pedro Rodríguez, corresponsal de $A B C$ en EE.UU., en su crónica publicada el mismo día 11: «El pánico hizo multiplicar aún más la magnitud de la tragedia. Si en un primer momento se informaba de un coche bomba en el Departamento de Estado, testigos presenciales lo desmentían posteriormente. Poco antes de esos informes, un periodista de la AFP que abandonaba el edificio del Departamento de Estado tras las órdenes de evacuación, escuchó dos explosiones pero no pudo identificar su origen. El ruido pudo haber sido causado por las explosiones en el Pentágono» ${ }^{12}$.

La información, por tanto, se organiza en este tipo de periodismo de catástrofes sobre la base de testigos, supervivientes, las agencias informativas, otros medios de comunicación, estimaciones extraoficiales, rumores, policía, bomberos, protección civil y fuentes sanitarias. Se entrelazan caóticamente todos los discursos informativos como un reflejo de la situación excepcional.

Como última nota característica añadamos que el periodismo de catástrofes tiene un reflejo destacado en los medios de comunicación, ya que ocupa espacios importantes en las portadas de los periódicos, las tertulias radiofónicas o los informativos televisivos. Este hecho es perfectamente constatable, sobre todo si tenemos en cuenta que las consecuencias derivadas de las catástrofes, especialmente de las masacres terroristas, se han incrementado notablemente en los últimos 30 años ${ }^{13}$. Por este motivo, y especialmente tras los atentados del 11-S, se ha puesto en evidencia la necesidad de aplicar los instrumentos legales existentes contra el terrorismo ${ }^{14}$. Los periodistas que trabajan en estos temas tampoco deben desconocer ni olvidar la existencia de estas normativas garantizadoras de los Derechos Humanitarios Internacionales.

$12 A B C$, número especial, 11-9.01, pág. 7

13 Pongamos como ejemplos los atentados del integrismo islámico, destacando la red de Al Qada. Los más de mil muertos ejecutados por la organización ETA. Los actos de violencia cometidos por otros grupos terroristas asentados en Europa. Los terroristas de Chechenia en Rusia; los terroristas kosovares; los terroristas palestinos... Pero tampoco olvidemos las violaciones de los derechos humanos en las que incurren sistemáticamente los gobiernos en su lucha contra el terrorismo, donde sufren las consecuencias muchas víctimas inocentes: los bombardeos israelíes organizados por Sharon contra los palestinos, Milosevic y su depuración étnica, el bombardeo de civiles en Afganistan, etcétera, etcétera.

14 Con motivo del aniversario del 11 de septiembre, el Grupo de Trabajo de Políticas de la ONU y el Terrorismo han elaborado un documento sobre medidas para eliminar el terrorismo internacional. Este informe de la Organización de las Naciones Unidas incluye 31 recomendaciones concretas y su objetivo principal es no dejar impune ningún acto terrorista, independientemente de la ideología o la causa que lo genere, y denunciar también las violaciones de los derechos humanos en las que incurran los gobiernos en su lucha contra el terrorismo. Además, tras los atentados del 11-S, el Consejo de Seguridad de la ONU aprobó en 2001 por unanimidad las resoluciones 1368 y 1373 en las que los estados miembros se comprometían a dar una respuesta multilateral al terrorismo. 


\section{Cobertura de las noticias de catástrofes: el 11-S}

El 11-S cogió por sorpresa a las redacciones de todos los periódicos. Nadie podía imaginar un acto terrorista de tal calibre y además en el centro económico y militar de la primera potencia del mundo. Como explica el catedrático de Derecho Internacional, Juan Antonio Carrillo Salcedo: «El atentado terrorista que golpeó a Nueva York y Washington supuso la entrada en escena de un nuevo tipo de agresores desconocidos e invisibles, y puso de manifiesto la vulnerabilidad del mayor poder bélico, económico y político del mundo» ${ }^{15}$.

Todas las catástrofes, al ser inesperadas, ya sean naturales o provocadas, generan gran incertidumbre en el momento de tener que cubrir este tipo de informaciones. En el caso del 11 de septiembre esa incertidumbre y sorpresa se eleva a la enésima potencia, debido a su gravedad y sus consecuencias.

El Instituto de la Prensa de la SIP, en un seminario organizado sobre la «Cobertura de la noticia de catástrofe», ha querido preparar a los periodistas para cubrir una catástrofe con eficiencia y sensibilidad. En este sentido, se recomienda a los jefes de redacción, reporteros, editores gráficos y fotógrafos lo siguiente: «Cuando la noticia explota repentinamente, el periódico debe responder al instante con una cobertura masiva y compleja en medio del caos. Ya sea un ataque terrorista, terremoto, ciclón, incendio, inundación o cualquier otro desastre. Es enorme el reto de obtener, filtrar o difundir información objetiva y fiable» ${ }^{16}$.

Como se apuntaba anteriormente la información referida al número de víctimas es una de las más complicadas. Los cronistas de estos hechos manifiestan, en forma de coletilla, la expresión de que «nunca se sabrá exactamente el número real de víctimas», ya que es un dato muy difícil de constatar. Igualmente, el número que reflejan los medios de comunicación sobre los desaparecidos es un dato casi siempre estimativo.

Se va informando sobre el número de cadáveres recobrados $\mathrm{y}$, a menos que el número sea reducido, no se suministran datos personales. También el periodista debe proporcionar el número de personas evacuadas (total aproximado o por familias), el lugar de residencia, los sitios donde fueron alojados y estado sanitario general; detallando especialmente el número de niños, así como el número de familias que perdieron sus viviendas.

Como recomendación de uso, Camps y Pazos indican que los periodistas que cubran una catástrofe deben explicar en sus crónicas las causas que han provocado el desastre, consultando fuentes especializadas. Los pasos a seguir para cubrir estas informaciones son los siguientes: aclarar si se trata de un fenómeno aislado o cíclico,

15 CARRILlO SALCEDO, Juan Antonio: «Un año después», en el suplemento 'El día que cambió el mundo', Diario de Sevilla, 11-9-02, pág. 22.

16 Se trata de un seminario conducido por Sibila Camps, experta en periodismo de catástrofes, los días 6 al 8 de diciembre de 2001. Web: www.ijnet.org, del International Center for Journalist (ICFJ). 
Periodismo de catástrofes: el 11 de septiembre. Análisis del suceso y experiencias vividas

precisar si fue o no pronosticado, destacar si hubo catástrofes similares en esa zona y qué consecuencias tuvieron, remarcar su magnitud en relación con las anteriores y especificar si las consecuencias podían ser atenuadas mediante la realización de determinadas obras o la evacuación preventiva ${ }^{17}$. Vemos que se trata de normas periodísticas a seguir en caso de catástrofes fundamentalmente de origen natural, pero pueden ser perfectamente aplicables a catástrofes provocadas.

La realidad es que la magnitud y el impacto de una catástrofe no se pueden explicar ni describir únicamente con datos científicos o técnicos: "Siempre será imprescindible el relato minucioso de cómo la gente vivió ese momento, de lo que vio, oyó, sintió, supuso, imaginó y hasta soñó durante los días siguientes" ${ }^{18}$.

Los periodistas deben conocer, desde el punto de vista normativo, la existencia de diversos documentos que ponen de manifiesto la necesidad que tienen los Gobiernos de adoptar acciones coordinadas, de protección y asistencia en estas situaciones. Así tenemos la Declaración de Pekín, adoptada durante la XI Conferencia Mundial de la Protección Civil (26-28 de octubre de 1998, Pekín, República Popular de China), donde se recoge que «la protección y asistencia frente a las catástrofes naturales y ocasionadas por el hombre son un derecho fundamental del ser humano, al igual que el derecho a la vida y a la salud» ${ }^{19}$.

Además existen diferentes resoluciones de la Asamblea General de la ONU en materia de la gestión de situaciones de catástrofes; en particular la Resolución 2034, que invita a los Gobiernos a trazar un plan nacional apropiado de planificación y de acción, con vistas a coordinar el mando de las operaciones de socorro y prevención ${ }^{20}$.

Sobre este asunto también se han hecho críticas al respecto, por parte de los medios de comunicación, al considerar que Estados Unidos, a través de sus servicios secretos como el FBI, tenía información previa de un posible ataque terrorista y no se utilizaron las medidas de prevención y protección debidas.

\section{Análisis de las portadas de $A B C, E l$ País y El Mundo: el día después al atentado:}

Se han seleccionado estos tres diarios, de ámbito nacional, por ser los de mayor tirada en España. Un análisis de las portadas de los tres periódicos, el día después del atentado, ofrece información suficiente para poner de manifiesto un suceso que se ha convertido en una de las mayores catástrofes mundiales de los últimos años.

La contraportada del número especial, en edición vespertina, que publicó $A B C$ el mismo 11 de septiembre, ofrecía el siguiente titular, suficientemente

17 CAMPS, S. y PAZOS, L.: Op. cit., pág. 186.

18 Ibídem, pág. 196.

19 Web: www.proteccioncivil.org/informes/cmpcxi.htm, que toma como fuente la Organización Internacional de Protección Civil (OIPC), Suiza, noviembre de 1998.

20 Web citada. 
aclaratorio de la gravedad de la noticia: «Golpe a los centros neurálgicos militar y económico de la potencia americana (antetítulo). El ataque contra el corazón de EE.UU. provoca una catástrofe mundial (título)»

Las portadas del miércoles 12 de septiembre de 2001 dedican por completo su espacio a esta noticia, con grandes titulares y predominando el elemento gráfico, la fotografía, como prueba fehaciente de la magnitud de la tragedia provocada.

\section{$\underline{A B C:}$}

Es de los tres el único diario que señala a Bin Laden como el «principal sospechoso» del acto terrorista, incluyendo en la parte superior derecha de la portada una foto del mismo, con el siguiente pie de foto: «Bin Laden, el enemigo público número uno de EE.UU., principal sospechoso».

El resto del espacio de la portada lo ocupa una fotografía que muestra el aspecto que presentaban las inmediaciones del lugar del atentado y al fondo se observan los restos de las Torres Gemelas destruidas.

Hay que señalar que $A B C$, a diferencia de El País y El Mundo, ofrece una imagen más periodística, de la agencia Ap, ya que no muestra la repetida imagen de las Torres Gemelas ardiendo, sino el aspecto que tienen las mismas después del ataque terrorista, una vez destruidas.

En este sentido, hay que destacar que $A B C$ sacó a la calle una edición vespertina que recogía en portada la impresionante foto de las Torres Gemelas envueltas en llamas. Por su parte, los otros dos diarios también publicaron, el mismo 11 de septiembre, números especiales dedicados al atentado, con gran despliegue informativo y gráfico, incluyendo editoriales, artículos de destacadas firmas de la política, la cultura y la economía.

$A B C$ publica cinco titulares en su portada, cuatro de ellos a modo de sumario y el quinto como titular principal, de mayor cuerpo y destacado en la parte inferior de la página. Este titular principal señala: «El ataque provoca miles de muertos (antetítulo). El terrorismo islámico declara la guerra a Occidente (título)». El resto de titulares son los siguientes: «Dos aviones destruyen las Torres Gemelas en Nueva York», «Otro aparato se estrella contra el Pentágono», «Una aeronave estalla cerca de Pittsburgh» y «Tensa calma en Morón y Rota con las bases en alerta máxima».

Además se hace una llamada al contenido del periódico, destacando el artículo de Tercera del director de $\mathrm{ABC}$, un editorial y un tratamiento sobre este asunto que ocupan desde la página 2 a la 36, un total de 34 páginas del periódico.

Este diario califica el atentado del 11 de septiembre como «el mayor ataque contra la estabilidad del planeta desde la Segunda Guerra Mundial» ${ }^{21}$. Otros calificativos utilizados por $A B C$ para explicar a sus lectores el 11-S son: «Aten-

$21 A B C$, número especial, 11-9-01, portada. 
Periodismo de catástrofes: el 11 de septiembre. Análisis del suceso y experiencias vividas

tado», «Ataque, Terrorismo islámico», «Ofensiva terrorista», «Guerra terrorista» y «Tragedia absoluta» ${ }^{22}$.

Desde el punto de vista del tratamiento informativo de esta noticia, $A B C$ destaca en su portada del 12 de septiembre tres aspectos: el primero, que el 11$\mathrm{S}$ es una declaración de guerra a Occidente por parte del terrorismo islámico; en segundo lugar, que Bin Laden es el principal sospechoso; y por último, los miles de muertos provocados.

\section{El País:}

Ofrece una portada, al estilo de $A B C$, ocupando un solo tema toda la página. Una gran fotografía, que ocupa la mitad del espacio de la portada, recoge el momento en el que se cae una de las Torres Gemelas de Nueva York. Es una imagen impactante, ya que da la impresión de una ciudad ardiendo completamente, una imagen bélica, una ciudad convertida en fuego y destrucción.

La parte superior de la portada se abre con un título de gran cuerpo y un antetítulo de menor tamaño, separado por un filete. En la parte inferior, a modo de pie de foto y a tres columnas, se incluye otro titular y un pequeño texto.

El titular principal expresa: «El mundo en vilo a la espera de las represalias de Bush». El título inferior señala: «Se teme que haya miles de muertos entre los escombros de las Torres Gemelas de Nueva York y el Pentágono».

El País informa a sus lectores sobre esta noticia empleando los siguientes términos: «El peor ataque de la historia de EE.UU.», «La peor crisis desde la II Guerra Mundial» y «Sello inconfundible del conflicto árabe-israelí».

Este diario destaca informativamente en su portada dos consecuencias del 11-S: las represalias previsibles del presidente de Estados Unidos ante el atentado y las miles de víctimas mortales que puede haber causado el ataque.

\section{El Mundo:}

Al igual que El País, su portada está ocupada por una gran fotografía que llena más de la mitad del espacio de esta página, y el resto está insertado de titulares y sumarios.

La fotografía, cuya procedencia aparece bajo la firma de AP/NBC, es también de una gran espectacularidad. Plasma el momento del impacto del segundo avión en una de las Torres Gemelas, mientras se observa como la primera arde tras estrellarse contra ella el primer aparato. Son imágenes, en primer plano, de las dos torres ardiendo y una gran humareda que envuelve todo el fondo.

La parte superior de la portada está ocupada por un titular principal en negrita que indica: «El mayor ataque terrorista de la Historia derriba los símbolos del poder de EE.UU. y causa más de 10.000 muertos y heridos».

$22 A B C$, número especial, 11-09-01, portada y contraportada; y $A B C, 12-09-01$, portada. 
También se recogen dos sumarios. Los titulares del pie de página van encabezados a tres llamadas: la primera sobre el editorial del interior, titulado «Una infamia que cambiará el mundo y marcará nuestras vidas»; la segunda llamada, con el encabezamiento de 'Análisis', indica las firmas de Felipe Sahagún y M. Leguineche; Eugenio Trías y Javier Echevarría; y Robert Samuelson y Juan Iranzo, correspondientes a los artículos publicados en el interior del periódico, que analizan el suceso bajo el ángulo diplomático, filosófico y económico, respectivamente. En tercer lugar se remite a la página web del mundo, www.elmundo,es, para que los lectores tengan un seguimiento más actualizado.

El Mundo, a la hora de calificar el 11-S, hace mención a la siguiente terminología: «El mayor ataque terrorista de la Historia», «Atentados suicidas», «Crisis mundial» e «Infamia».

Desde el punto de vista del tratamiento de la noticia, este diario resalta cuatro aspectos: que se trata del mayor ataque terrorista de la Historia ${ }^{23}$; el elevado número de víctimas mortales y heridos; las reacciones de Bush: «Cazaremos y castigaremos a los responsables»; y el hecho de considerar que es un acto de «cambiará el mundo».

Conclusiones:

1. Elementos comunes que aportan informativamente los tres diarios:

a) El 11-S es uno de los actos de agresión internacional más graves desde la II Guerra Mundial.

b) Ha supuesto un grave ataque al poder económico y militar de la primera potencia mundial.

c) Se trata de un ataque terrorista.

d) Los tres diarios destacan en sus portadas el elevado número de víctimas, elemento característico de la información de catástrofes. En cuanto al número de víctimas, $A B C$ y El País estiman que el ataque ha provocado «miles de muertos» y El Mundo concreta la cifra en «más de 10.000 muertos y heridos».

2. De los tres diarios es $A B C$ el que claramente considera el 11-S como una «catástrofe mundial». Sin embargo, El País y El Mundo incluyen en sus informaciones elementos comunes del periodismo de catástrofes como: elevado número de víctimas, crisis social y política, conflicto, tragedia....

3. La información gráfica predomina en las portadas frente a la información textual. Predominio de lo visual sobre los titulares: función de anuncio o entrada a la información interior de los diarios.

4. Gran despliegue informativo en páginas interiores de los tres diarios, con editoriales y análisis de firmas de conocidos articulistas y expertos.

5. En relación con los titulares, todos son impactantes (efecto impacto) y de estilo claramente opinativo.

23 Aparece la palabra Historia con mayúsculas, lo que hace suponer que se refiere a la historia del mundo en general. Por tanto, el mayor ataque terrorista de los acontecidos en el mundo a lo largo de su historia. 


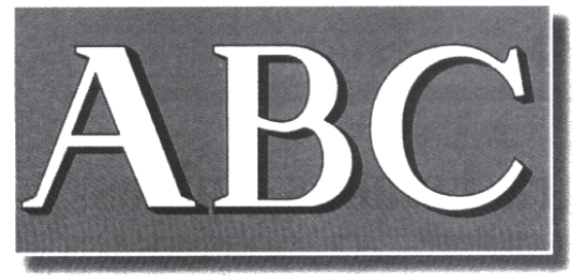

SEVILLA • MIÉRCOLES • 12 DE SEPTIEMBRE DE 2001150 PTAS. • 0,90 EUROS

\section{Bin Laden, el enemigo público «número uno» de EE.UU., principal sospechoso}

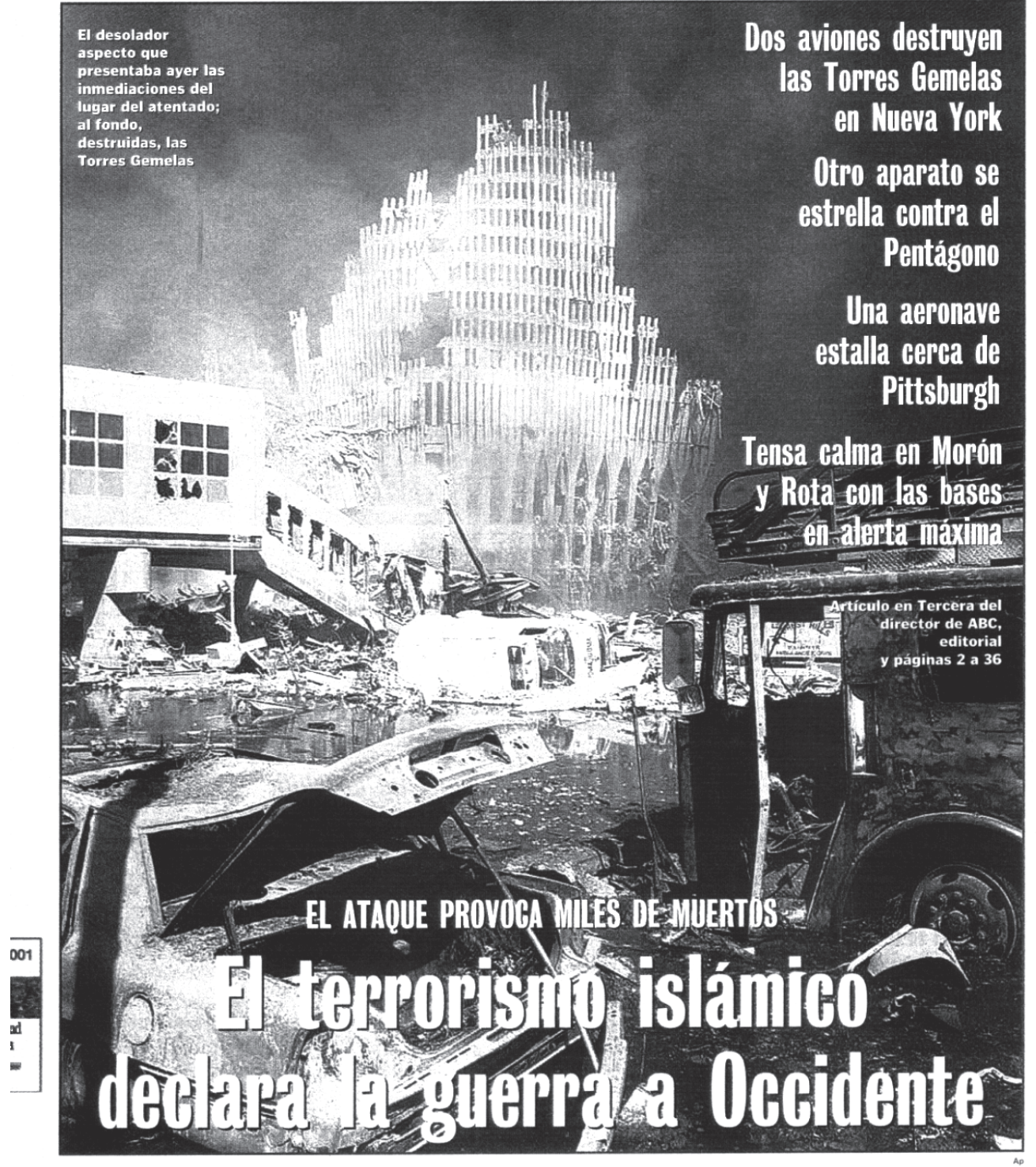




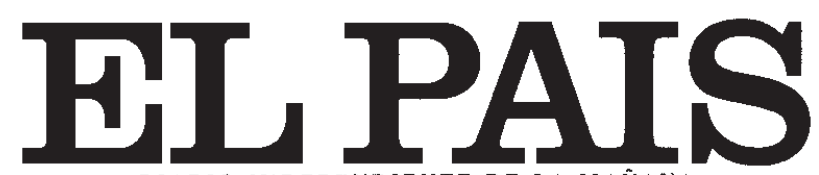

\section{EE UU sufre el peor ataque de su historia}

\section{El mundo en vilo a la espera de las represalias de Bush}

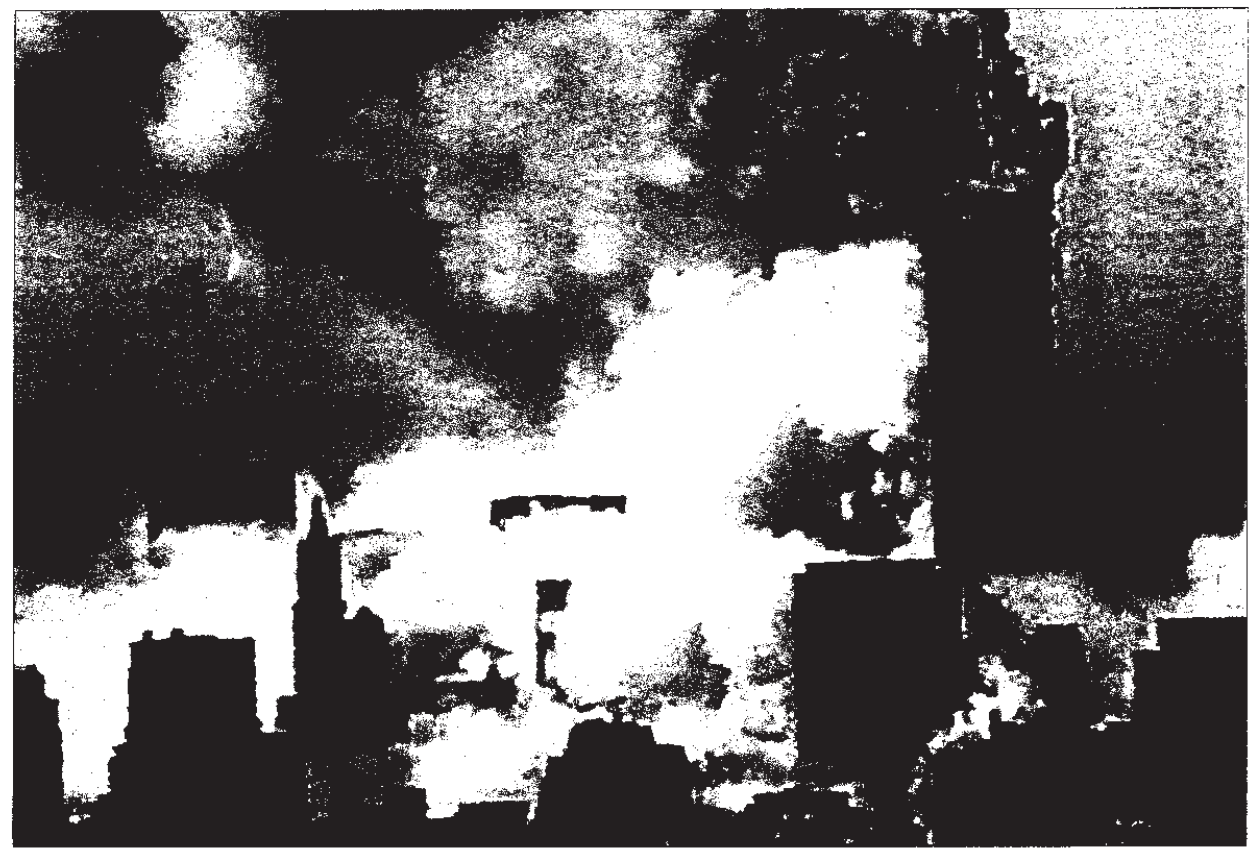

Se teme que haya miles de muertos entre los escombros de las Torres Gemelas de Nueva York y el Pentágono

George Bush garantizó ayer a los norteamerica- ese castigo, el mundo entero contiene la respira- con el sello inconfundible del conflicto árabe-isnos que se han tomado todas las medidas ade- ción ante la peor crisis desde la II Guerra Mun- raelí, fue perpetrado con cuatro aviones de pasacuadas para proteger la vida de los ciudadanos dial. Las autoridades temen encontrar miles de jeros secuestrados por terroristas suicidas y lany prometió que "EE UU agarrará y castigará a muertos entre los escombros de las Torres Geme- zados después contra los objetivos, dos de los los responsables de estos actos cobardes". A la las y el Pentágono. El ataque, no reivindicado edificios nás caracteristicos del poder económiespera de la proporción y las consecuencias de todavía de forma creíble por ningún orupo, pero co y militar norteamericano. Página 2 a 25 


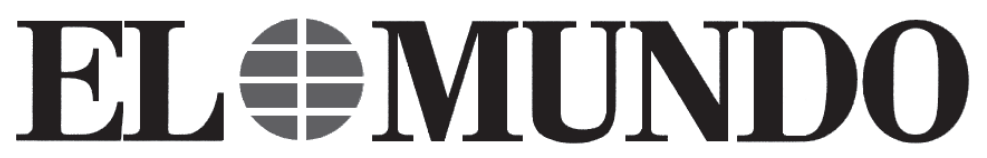

\section{El mayor ataque terrorista de la Historia derriba los símbolos del poder de EEUU y causa más de $\mathbf{1 0 . 0 0 0}$ muertos y heridos}

- Todas las sospechas por los atentados suicidas con aviones de pasajeros secuestrados, que destruyeron las Torres Gemelas de Nueva York y parte del Pentágono en Washingtom, apuntan al integrismo islámico Reserva Federal garantiza que habrá dinero en los bancos tras caer las Bolsas y dispararse el precio del crudo

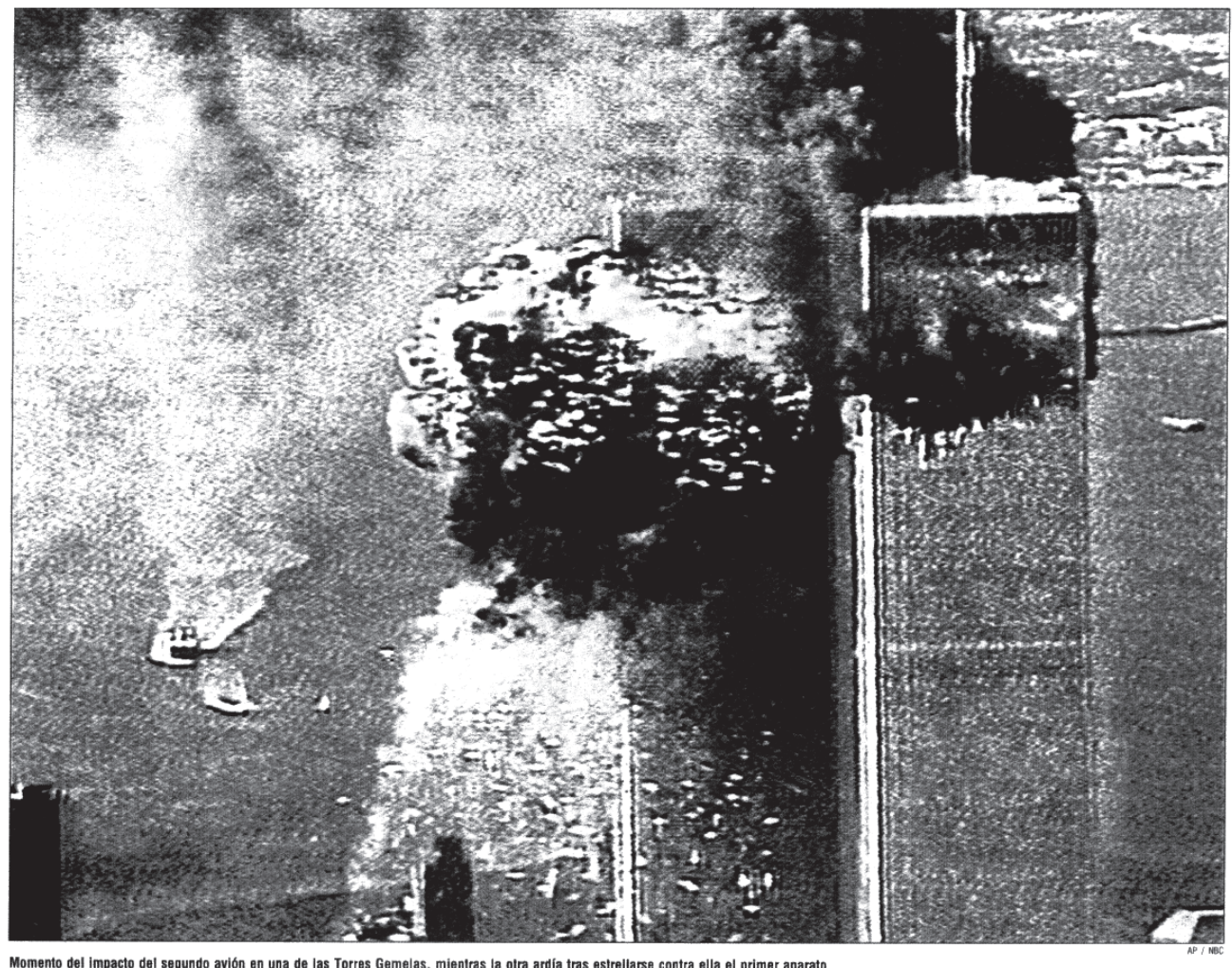

Momento del impacto del segundo avión en una de las Torres Gemelas, mientras la otra ardía tras estrellarse contra ella el primer aparato.

EDITORIAL

Una infamia que cambiará el mundo y marcará nuestras vidas / Página 21
ANALISIS

El ángulo diplomático por Felipe Sahagún y M. Leguineche El ángulo filosófico por Eugenio Trías y Javier Echeverría El ángulo económico por Robert Samuelson y Juan Iranzo
28 páginas con toda la información Siga la crisis mundial al minuto en www.elmundo.es 


\section{2a PARTE: \\ EXPERIENCIAS VIVIDAS}

M. Ángeles Martín Ruiz

\section{DE SEPTIEMBRE: NUEVA YORK}

El 11 de septiembre de 2001 ha marcado un antes y un después en la historia contemporánea, pero esta fecha ha servido también de precedente para un nuevo modelo de comunicación.

Viajar a lugares donde existen guerras internas, fuertes conflictos políticos, religiosos, étnicos o culturales ha supuesto siempre un desafío para el viajero o para los profesionales de la comunicación en el desempeño de su trabajo que tratan siempre de mantener, en este tipo de escenario, sus sistemas de alerta encendidos y fabricar con antelación planes de huida y seguridad ante una evidente vulnerabilidad. Lugares como Colombia, Irak, Chechenia, Israel o Afganistán integran esta lista negra donde las situaciones de riesgo se dan por doquier y donde nadie, salvo las personas que lo viven, son conscientes de lo que se ve y lo que se siente. Hablar de Nueva York como integrante de esta lista hubiera sido impensable hace poco más de un año; el 11 de septiembre de 2001 cambió esta afirmación y convirtió, a la entonces intocable capital del mundo, en uno de los lugares más vulnerables e impotentes de la tierra.

En varias ocasiones durante mi estancia en Nueva York me acerqué al World Trade Center invadida por su increíble majestuosidad. Dos días antes del fatídico día, concretamente a las 11.00 horas, me encontraba en la planta 98 de la Torre Norte. Allí visité a un amigo en su oficina, visita que aproveché para conocer un edificio que se había convertido en un símbolo de poder en la ciudad. Comprobé desde esa altura la inmensidad de la ciudad y también el vértigo que suponía estar a muchos metros de altura, un vértigo que era notablemente amortiguado por la configuración, algo más estrecha de los hombros, de las ventanas. Allí trabajaban muchos miles de personas, en torno a las 40.000, en cientos de empresas en las que se movían los hilos de la economía mundial. Cuando me despedí de mi amigo, no podía imaginar que me despediría para siempre, y que, dos días después, su nombre sería uno de los 2.823 que engrosaban una lista de víctimas y desaparecidos.

El día 10 de septiembre ultimé los preparativos de mi vuelta, ya que, a las 20.00 horas del día siguiente, mi avión partiría rumbo a París. La ciudad estaba siendo azotada por una terrible tormenta, aunque los pronósticos del tiempo para el día siguiente eran bastante alentadores: sol y temperatura agradable para la jornada del martes. Nada hacía presagiar los fatídicos y terroríficos actos que se cometerían en tan sólo unas horas. 
Periodismo de catástrofes: el 11 de septiembre. Análisis del suceso y experiencias vividas

\section{1 de septiembre de 2001:}

El día amaneció soleado, tal y como había sido pronosticado, y el pulso cotidiano de la ciudad surgía, una mañana más, con todo su énfasis y energía. Yo vivía en un lugar privilegiado dentro de la gran manzana, privilegiado porque mi apartamento se encontraba a una milla escasa del Worl Trade Center, y porque el ritmo vertiginoso y acelerado de la zona económica y financiera del mundo se hacía notar en el vecindario, imprimiendo esa sensación de movimiento que me hacía sentir viva y activa desde primeras horas de la mañana. Desde el portal de mi edificio de veinte plantas imperaba sólo una imagen: las Torres Gemelas. Formaban parte del perfil idílico de Nueva York y creaban un contorno único en una ciudad ahora mutilada en uno de sus extremos. Puse la radio como cada mañana al despertar y comprobé, un día más, el optimismo y el patriotismo que imprimen a sus crónicas los locutores neoyorquinos, en una ciudad en la que conviven más de diecisiete millones de habitantes de todas las precedencias imaginables.

"Aunque no lo crea usted está en Nueva York, la capital del mundo"; "Vamos, levántese ya, hoy es maravilloso estar en Nueva York, la previsión atmosférica es soleada y eso no se lo puede perder"; "Buenos días América, no pierda el tiempo, levántese, sobre todo si está en Nueva York"....eran despertares radiofónicos cotidianos que, el 11 de septiembre de 2001, también se dejaron sentir en torno a las 7.00 horas de la mañana. Era mi último día en la ciudad, tras más de mes y medio de estancia, y quería aprovechar hasta el último minuto del tiempo que me quedaba hasta las 15.00 horas, ya que pasarían a recogerme para conducirme al aeropuerto internacional John Fizgerald Kennedy donde tomaría mi vuelo rumbo a Europa.

Dispuesta a salir a la calle, el teléfono sonó, inusualmente, en torno a las 8:50 de la mañana. Lo cogí, algo sorprendida, pero me tranquilicé cuando escuché la voz de la persona que pasaría a recogerme a media tarde. Su voz sonaba nerviosa y fue la encargada de darme la preocupante noticia. A escasos metros de donde me hallaba había sucedido un terrible accidente, un avión había chocado contra una de las Torres Gemelas. En una ciudad donde millones de personas se desplazan a diario hacia todos los rincones del mundo y donde el espacio aéreo está siempre ocupado por aviones que los transportan, no es impensable que algo así pudiera suceder. Incluso existía un precedente en la historia de Nueva York protagonizado por el otro gran coloso de la ciudad, cuando una avioneta se estrelló, hace años, contra el piso 80 del Empire State Building.

Una vez conocida la noticia, llamé por teléfono a España e informé a mi familia de lo que estaba ocurriendo. Inmediatamente mi madre puso la televisión y curiosamente, mientras yo hablaba con ella, comenzó a ver las imágenes que encabezaban todos los telediarios de las 15.00 horas, y que yo, a escasos metros aún no había visto. En ese momento pensé en la celeridad y en los cambios que 
la información tradicional estaba sufriendo. Sin duda, estábamos ya en otra era, en cuanto a comunicación se refiere, y estábamos entrando, en ese mismo instante, en otra era con respecto a la situación internacional dominada por Occidente.

Bajé inmediatamente a la calle y vi el terrible accidente. La torre norte estaba en llamas en su tercio superior, el humo negro invadía poco a poco todo el edificio, era impresionante. La gente estaba conmocionada ante el fatal suceso pero guardaba la calma. Comencé a acercarme a la zona, cuando de pronto, un segundo aparato de grandes dimensiones se acercaba a la torre sur. A escasos metros el avión realizó un extraño viraje y se estrelló, casi atravesándola por completo, en torno a la mitad de la torre. Fue algo indescriptible!. Aquello no había sido un accidente, aquello había sido un ataque. La gente comenzó a gritar, a correr, nadie podía creer lo que estaba sucediendo en la ciudad de Nueva York. Aquella soleada mañana neoyorquina dejó a la gente boquiabierta viendo como dos aviones se estrellaban contra las Torres Gemelas del World Trade Center. Desde esos primeros momentos la angustia y el pánico comenzó a sentirse en la población, la gente lloraba porque sabía que las víctimas serían muchas, gritaban, rezaban, los nervios comenzaban a aflorar. También había gente que continuaba desayunando tranquilamente mientras contemplaban el espectáculo del terror a través de los escaparates del establecimiento. En ese momento me di cuenta que estaba en Nueva York, en una ciudad cosmopolita donde puedes encontrar de todo. Muchos de los comercios de la zona comenzaban a cerrar sus puertas con letreros en los que se leía "Close due the tragedy" (cerrado por la tragedia). El tráfico rodado quedó interrumpido, muchos abandonaban sus coches en medio de esa jungla en la que se habían convertido las calles del sur de Manhattan. La palabra terrorismo comenzó a rondar en la mente de muchos. La radio de los coches y los televisores, que muchos comercios habían sacado a la calle, comenzaban a dar las claves de lo que estaba ocurriendo en la ciudad: dos aviones comerciales de American y United Airlines cargados de pasajeros y secuestrados en pleno vuelo por terroristas suicidas, habían impactado sobre las Torres Gemelas, a la vez que aterrorizaban a los habitantes de Nueva York. Habían sacudido no sólo el corazón de Manhattan, también el de Occidente.

Lo más singular de todo lo que estaba ocurriendo aquel 11 de septiembre radicaba en que, la espectacularidad de la tragedia, estaba siendo observada por el ojo implacable de las cámaras e iba a quedar impreso en la memoria colectiva del mundo.

Seguí acercándome con cautela a la zona del desastre entre una multitud que corría en sentido contrario, alertados por la policía que intentaba desesperadamente evacuar la zona. Coches de policía, camiones de bomberos y ambulancias comenzaron a abrirse camino en unas calles colapsadas de vehículos y de coches. La zona comenzaba a acordonarse, sólo los servicios de emergencia podían acercarse hasta las inmediaciones. Me acerqué lo suficiente como para ver, claramente, 
Periodismo de catástrofes: el 11 de septiembre. Análisis del suceso y experiencias vividas

como decenas de personas se arrojaban por las ventanas para escapar de las llamas que le auguraban una muerte segura. Esas imágenes y esos sonidos jamás podré olvidarlos. Tampoco la sensación de ver a seres humanos muriendo a escasos metros y no poder hacer nada. En ese momento me acordé del vértigo que sentí, tan sólo dos días antes, al asomarme a una de esas ventanas. Un escalofrío recorrió mi cuerpo. Me acordé de mi amigo y confié en que no estaba trabajando.

Las cadenas de televisión continuaban emitiendo, casi al unísono, la pesadilla que se estaba viviendo en Nueva York. La mayoría de la gente seguía, a través de los medios de comunicación, los avances de lo que allí estaba ocurriendo. Todo dio un nuevo rumbo, cuando, de repente, los noticieros avanzaron que un tercer avión había impactado contra el Pentágono, destruyendo parte de sus instalaciones. Aquello parecía el fin, ¿qué estaba pasando en el mundo?. Sentí deseos de comunicarme con mi familia, cuando alguien me informó que todas las comunicaciones estaban cortadas: teléfonos fijos, móviles, Internet...las autoridades hacían llamamientos para que, en caso de funcionar algún tipo de comunicación, nos abstuviéramos de usarla y facilitar así las llamadas de emergencia que provenían de las torres, así como la de los equipos de rescate. Continuaban llegando policías y bomberos que intentaban evacuar a las miles de personas que se encontraban aún dentro de los dos edificios que se habían convertido en una trampa mortal.

Una nueva noticia sacudió a los neoyorquinos: un cuarto avión había sido secuestrado y se dirigía, presumiblemente, a la Casa Blanca, para golpear el poder político, el único que se había salvado de la destrucción. No dio tiempo a reaccionar porque, lo peor estaba aún por llegar. Alrededor de las 10.00 horas la torre sur, la que recibió el segundo impacto, caía desplomada y quedaba, a escasos segundos, reducida a escombros, arrastrando con ella a miles de personas que trataban desesperadamente de salir de su interior. Cientos de policías y bomberos que participaban en el desalojo vieron como la muerte, en forma de acero, hierro y escombro, se los llevaba por delante.

El súbito derrumbe nos pilló a todos desprevenidos. Tuve que salir corriendo de la cercana calle en la que me encontraba, junto a decenas de personas, muchos de ellos periodistas, para evitar que los escombros y el polvo me atrapara, algo que, pese a mis esfuerzos, no conseguí. Todo el mundo, en cuestión de segundos, quedó inundado por las secuelas del derrumbe.

Nos enteramos, a través de los improvisados altavoces en los que se habían convertido los televisores y radios de algunos comercios, que este último avión se estrellaba finalmente en los alrededores de Pittsburg, en el estado de Pennsylvania. ¿Era estrellado en una revuelta de los propios pasajeros tal y como se oía o, por el contrario, era derribado por las fuerzas aéreas norteamericanas?. Decenas de preguntas se venían a mi cabeza mientras me encontraba en una espiral de terror jamás imaginable. El caos en la ciudad de Nueva York era evidente, las autorida- 
des, pese a sus esfuerzos, no podían combatir lo que se les venía encima. En pocos minutos se volvió a oír un estruendo ensordecedor y la tierra comenzó a latir bajo mis pies, la segunda torre cedía implacable. La verticalidad con la que ambas estructuras cayeron contribuyó a no extender el desastre a las zonas más inmediatas y evitó, en cierta medida, una catástrofe mayor.

Seguíamos corriendo despavoridos, incontrolados y casi con el rumbo perdido a causa del pánico, hacia la zona norte de Manhattan alentados por las autoridades. El espectáculo era infame. Miles de personas heridas, cubiertas de sangre, llantos, gritos, desesperación... se mezclaban en un escenario terrorífico. En los hospitales más cercanos se amontonaban heridos y cadáveres. Se hablaba ya de miles de víctimas. Muchos de los afectados por la tragedia eran trasladados a los parques cercanos e iban siendo atendidos, en función de su gravedad, por los servicios de urgencias que se vieron desbordados. Bolsas negras con restos humanos comenzaron a hacer su aparición en la zona del desastre. Los hospitales se preparaban para la llegada masiva de heridos, que fue mucho menor de la esperado: médicos, enfermeros, voluntarios se disponían a afrontar la jornada más dura de su vida, mientras se solicitaba, con desesperación, donaciones de sangre para los heridos, algo a lo que la población contribuyó en gran medida en un intento desesperado de poder ayudar y ser útiles. Las evacuaciones continuaban y las comunicaciones seguían cortadas. El tráfico en la red de metro y en trenes se interrumpió y se pedía a los conductores que facilitaran los accesos para los vehículos de emergencia. Los túneles y puentes de acceso a la isla fueron también clausurados. Miles de personas comenzaron su particular éxodo por calles, avenidas y puentes de Nueva York, en una ciudad sitiada y que continuaba bajo la amenaza terrorista. Los tres grandes aeropuertos de la ciudad fueron cerrados y las primarias de las elecciones locales, que se celebraban este día, fueron canceladas. Por primera vez en la historia el espacio aéreo norteamericano se cerró por completo y el personal de la Casa Blanca, el Capitolio y el Departamento de Estado fueron evacuados. La bolsa de Nueva York, cuyas dependencias se hayan muy cerca de la zona del desastre, suspendió sus operaciones, mientras las bolsas europeas y mundiales se fueron hundiendo poco a poco ante el temor a un colapso económico.

El mayor ataque terrorista en la historia de los Estados Unidos burló por completo a los servicios de inteligencia norteamericanos y dejó herido el corazón de su economía y su defensa, dejando el país paralizado y en máxima alerta militar tras los atentados. Las apariciones en los medios de comunicación del presidente norteamericano George W. Bush en las que prometía capturar a los responsables de esta matanza, no tranquilizaban a una población presa del pánico. La fragilidad y la vulnerabilidad del país se habían puesto de manifiesto, algo que traería, posteriormente, graves consecuencias sociales y psicológicas en la población. 
Las evacuaciones continuaron por todo el país, ante la amenaza de un nuevo atentado, declarándose algunos días después el estado de emergencia nacional, mientras en Europa se activaban planes de acción antiterroristas y eran evacuados el cuartel general de la OTAN en Bruselas y la bolsa de Londres, que cerró con una fuerte caída.

Entretanto, el FBI abría en Washington una investigación sobre los atentados más cruentos de la historia, dirigiendo las miradas a Oriente Próximo y, principalmente, a Osama Bin Laden, el millonario terrorista saudí refugiado en Afganistán.

Los diecinueve terroristas suicidas que secuestraron cuatro aviones y se estrellaron sobre objetivos civiles causando miles de víctimas, pertenecían a la organización Al Qaeda, comandada por Osama Bin Laden, que tiene su base de operaciones en Afganistán.

Este país asiático, convertido en el centro de una red terrorista mundial, constituía, mucho antes del 11 de septiembre de 2001 una amenaza para la estabilidad mundial. Sus continuas guerras, su pobreza, su sequía, el tráfico de droga y la presencia del régimen talibán, principal aliado del terrorismo de Bin Laden, debían haber alertado a Occidente de la posibilidad de un atentado. Pero los servicios de inteligencia fueron vilmente burlados y trajo, como consecuencia, el peor atentado de la historia de Estados Unidos, perpetrado en suelo americano, con aviones americanos y contra objetivos americanos.

La noche del 11 de septiembre resultó confusa y tétrica. La oscuridad y el silencio, sólo alterado por el ruido de las máquinas excavadoras, se apoderó de la ciudad. Algunas de las personas que estábamos evacuadas pudimos volver a nuestros hogares y comprobar cómo la ceniza y el polvo lo habían inundado todo. Algunos no pudieron volver a sus casas y muchos lo perdieron todo. Mientras, en el escenario de la tragedia, el humo y la desolación continuaban inalterables, y los voluntarios, reclutados a miles, hacían lo imposible por recuperar vidas humanas, mientras los edificios que formaban parte del entramado del World Trade Center amenazaban con desplomarse. Los supermercados de la zona estaban vacíos ante la posibilidad de seguir atrapados en la urna cerrada en la que se había convertido la isla de Manhattan. Sólo helicópteros y aviones de reconocimiento sobrevolaban la ciudad, una ciudad tomada por las fuerzas militares y en la que cientos de amenazas, sobre objetivos emblemáticos de Nueva York, fueron recibidas en esa primera noche.

Al día siguiente, el miedo y la inseguridad, continuaban adheridos a la piel de los que nos encontrábamos en Nueva York. Todo continuaba cerrado y el alcalde Rudolph Giuliani, pedía a la población que no fueran a trabajar, salvo que fuera imprescindible y que se quedaran en sus casas.

Las páginas de los periódicos se llenaron de artículos que abordaban la terrible noticia. Incluso el Wall Street Journal, cuya sede central fue arrasada en 
el desplome del World Trade Center, hizo un esfuerzo sin precedente para poder salir a la calle el 12 de septiembre elaborando, en las circunstancias más difíciles y de manera improvisada en unas dependencias de Nueva Jersey, la edición que informó de los graves acontecimientos.

La televisión continuaba informando en Nueva York las veinticuatro horas del día en un intento de ofrecer la última hora de lo que estaba ocurriendo en la zona. Lo hacían en un esfuerzo inconmensurable, ya que la dificultad que teníamos los periodistas para acceder a la ya denominada Zona Cero era inusual. En mi caso, con una modesta acreditación del hoy extinto periódico hispano de Nueva York El Latino News, del cual yo era colaboradora, podía ser normal, pero llegué a presenciar cómo equipos enteros de televisión eran retenidos e impedida su entrada. Los medios de comunicación, periodistas, locutores, nos amontonábamos en las inmediaciones con el fin de obtener alguna información. Jamás había visto a tantos comunicadores juntos en un esfuerzo por hacer llegar al mundo lo que allí estaba ocurriendo. Era curioso que cada vez que yo escribía algo en mi improvisada libreta realizada con papeles que habían sido expulsados de las torres, algún compañero se acercaba para saber si había tenido alguna noticia. Los nervios y la impaciencia se apoderaron también de los medios de comunicación.

Mientras en el resto del mundo los medios de comunicación ofrecían en directo las imágenes reiteradas, imágenes de destrucción, difundidas de un modo idéntico en episodios repetitivos, casi irreales, de los atentados, rehuyendo de los espectáculos de sufrimiento y muerte que no hacen más que alimentar el morbo de la audiencia. Se pone así de manifiesto la globalidad de un mundo en el que la información provoca, al mismo tiempo, el mismo efecto en lugares muy dispares y alejados entre sí.

La televisión fue, gracias a su inmediatez, el medio elegido por una audiencia que, en los momentos iniciales, demandaban gran cantidad de información. En los informativos de las cadenas, inusualmente largos, los telespectadores devoraban información habida cuenta de la magnitud, a escala mundial, que estaban teniendo los atentados. Otro de los medios que vio notablemente incrementada su demanda, fue Internet, que alcanzó en estos primeros días un récord absoluto de visitas.

Toda aquella fuente incansable de noticias, que fue perdiendo progresivamente el interés de la audiencia, fue capaz de mantenerse gracias a la aparición de la sombra del Ántrax y de una posible guerra bacteriológica que aterrorizó y sembró el pánico, una vez más, entre la población civil norteamericana, sabedores de que cualquier ciudadano podía ser el destinatario de la oleada de cartas que contenían el mortífero polvo blanco.

El inicio de los bombardeos de Estados Unidos, el 7 de octubre, contra Afganistán para intentar acabar con el régimen talibán y desestabilizar las células terroristas más buscadas del momento, la amenaza constante en objetivos europeos o la hipótesis de un nuevo episodio terrorista al producirse el accidente de avión, 
el 12 de noviembre, en el neoyorquino barrio de Queens, abrieron de nuevo el apetito informativo entre la audiencia.

Tras los sucesos sin precedentes y de consecuencias incalculables ocurridos el 11 de septiembre de 2001, no sólo asistimos a un cambio que reclama a voces la construcción de un nuevo orden internacional en el marco del siglo XXI, sino que, cambios tecnológicos muy radicales, se llevaron a cabo en los medios de comunicación y en el periodismo, entendido como tal.

El más catastrófico ataque terrorista de la Historia aún continúa vivo en la mente colectiva de buena parte del mundo, y que ha supuesto, en definitiva, un cambio revolucionario e insólito en el marco de la comunicación, debe de servir para dar cuenta al mundo de la complejidad por la que se rige la información y de los peligros y las dificultades a los que, profesionales de los medios, se enfrentan en el desempeño de la labor, que no es más que llegar y contar con rigor, tratando de evitar el peligro, que a veces te viene encima.

\section{Nueva York: un año después.}

Un año después la ciudad de Nueva York trata de recuperarse, poco a poco y con dignidad, del terrible atentado que la sacudió en lo más profundo aquel 11 de septiembre de 2001. Pero las dificultades y las secuelas se dejan sentir en una población todavía amedrentada y herida en sus cimientos. La evidente vulnerabilidad de la ciudad, a la que no estaban acostumbrados los neoyorquinos, abrió un nuevo abanico de emociones y sentimientos jamás experimentados por esta población que se creía, hasta la fecha, intocable.

El patriotismo ha subido de manera impensable sus cotas de adeptos, la prepotencia se ha vuelto humanismo y la necesidad de levantar una ciudad en la que se han perdido más de 95.000 puestos de trabajo, hacen que Nueva York se haya convertido hoy día en una ciudad nueva y muy diferente.

Cifras escalofriantes de muertos y desaparecidos recorren la ciudad, y los cuerpos de policía y bomberos, hoy convertidos en héroes, hacen todavía recuento de sus pérdidas y reconocen sus errores. Se buscan sustitutos que ocupen el lugar dejado por las torres y que reconstruyan las facciones de una ciudad hoy mutilada. Pero lo peor es el sentimiento de una sociedad, sacudida por sorpresa, y que unos años después continúa dañada. Así lo demuestra la entrevista que realicé el 28 de agosto de 2002, al Doctor Manuel Trujillo, director de Psiquiatría del Centro Hospitalario Bellevue de Nueva York, cuyo equipo fue uno de los primeros en desplazarse a la zona del desastre. Él mismo nos habla de la situación por la que pasan los neoyorquinos un año después y las consecuencias que este primer aniversario traerá consigo.

Lo cierto es que la ciudad de Nueva York continúa su camino de efervescencia y dinamismo. Trata de recuperarse y buscar el lado positivo a una situación sin precedente y, una vez más, la vida se impone al terror y, además, nos hace libre. 


\section{CIFRAS DE LA TRAGEDIA}

(Obtenidas de la Special Conmemorative Edition ${ }^{24}$ )

TOTAL DE MUERTOS: 2.823

IDENTIFICADOS: 1.102

DESAPARECIDOS: 1.721

POLICIAS MUERTOS: 23

OFICIALES DE LA AUTORIDAD PORTUARIA MUERTOS: 37 BOMBEROS MUERTOS: 343

TRABAJOS DE DESESCOMBROS: 3.100 .000 Horas

ESCOMBROS RETIRADOS: 1.642 .698 Toneladas

ACERO RETIRADO: 190.568 Toneladas

ESCOMBROS SUBTERRÁNEOS REMOVIDOS: 25.000 Toneladas

NUMERO DE CAMIONES USADOS: 108.444

AREA LIMPIADA: 16 Acres (dimensiones de 3 campos de fútbol)

ULTIMO FUEGO APAGADO: 20 de diciembre de 2001 
Periodismo de catástrofes: el 11 de septiembre. Análisis del suceso y experiencias vividas

\section{- ANEXO -}

El doctor Manuel Trujillo, director de Psiquiatría del Centro Hospitalario Bellevue de Nueva York desde el año 1991, ha sido profesor de psiquiatría clínica en diversas universidades y es vicejefe del departamento de Psiquiatría de la Universidad de Nueva York. Sevillano. Y su equipo fue uno de los primeros en desplazarse el 11-S a la zona del desastre.

- ¿Cómo han evolucionado mentalmente los neoyorquinos tras el 11-S?

La sociedad de Nueva York es muy diversa y podemos encontrar todo tipo de personas, por tanto, tendríamos que hablar en principio de los neoyorquinos en general y después de los grupos de poblaciones en particular.

Yo creo que, a los neoyorquinos en general, el primer aniversario les va a ayudar a pasar página, es decir, se van a hacer una serie de rituales espléndidos donde, por ejemplo, las bandas de música de los policías y los bomberos van a ir bajando de cada uno de los condados acercándose a la "zona cero" con músicas asociadas a los ritos funerarios y que estuvieron presentes en todos los funerales de los 343 bomberos que murieron. Además las familias tendrán la oportunidad de visitar la "zona cero" y, por tanto, van a restablecer por primera vez un contacto físico y directo con el recuerdo de sus seres queridos. En conversaciones que he tenido precisamente con el jefe de los sistemas forenses de la ciudad, desde octubre del año pasado tienen una idea exacta de donde se recogieron cada uno de los 30.000 restos humanos, y estos datos, van a ser comunicados a las familias que tendrán la oportunidad de poner flores en estos lugares y de alguna manera entrar en contacto.

Todo esto, en definitiva, va a posibilitar en general, que la ciudad pueda pasar página, lo cual implica un proceso que puede durar semanas o meses, de manera que toda esta memoria pasará del presente y de la actualidad al archivo de la memoria del recuerdo, donde se evocarán de vez en cuando con nostalgia, pero ya no serán parte de las vivencias diarias de la mayoría de los neoyorquinos, así los niveles de ansiedad y preocupación bajarán, aunque no a cero como antes del 11-S. Lo que sí quedará será una cierta incertidumbre sobre si volverá a repetirse, si habrá o no guerra con Irak, pero eso podríamos calificarlo como una pequeña alarma, ya que no es miedo ni angustia, sino incertidumbre, algo que el organismo registra y que conecta o no en función de la evolución del entorno.

En definitiva, la gran mayoría pasará página, de ahí la importancia que va a tener este aniversario. Los posteriores ya tendrán otro carácter, pero este dará paso a una etapa de reconstrucción, y donde ya la población, poco a poco, se irá liberando del duelo.

Todo esto admite muchas matizaciones en función de los grupos. Obviamente, a los grupos de riesgo les va a durar más tiempo el dolor. 


\section{medida? \\ ¿Qué capas de la población están sufriendo los traumas en mayor}

Se pueden clasificar bastantes grupos de riesgo. Los familiares de bomberos y policías, los que perdieron seres queridos, personas que han vivido otras situaciones de estrés traumático o postraumático en su vida y que vuelven los vuelven a activar, ya que los traumas representan como una llamada al sistema neurobiológico y psicológico del ser humano y vuelven a traer a la superficie traumas aunque sean muy antiguos. Los niños, por razones obvias de inmadurez y desarrollo representan también un grupo de alto riesgo a los que se le presta mucha atención, sobre todo a los que vieron o vivieron alguna situación de este tipo, bien por que estaban cerca de la "zona cero", bien porque perdieron a algún familiar, o bien por ambas condiciones.

En definitiva, el riesgo mayor de sufrir estrés postraumático es en primer lugar la persona que vive la situación traumática y la sobrevive, y en segundo lugar la persona que experimenta pérdidas importantes de un ser querido. De hecho hay una relación ya establecida por la epidemiología psiquiátrica entre exposición y riesgo del desarrollo del estrés, es decir, si se es un superviviente, si se pierde un ser querido, si se vivía cerca, si se perdió la casa o el negocio ... en estos casos el riesgo es mucho mayor. De hecho, hay como unas 120.000 personas con un riesgo de tipo número uno, un riesgo importante con pérdidas directas. Además, las encuestas han demostrado que entre el 20 y el $40 \%$ de las personas que tienen este tipo de riesgo han desarrollado síntomas abundantes de estrés traumático, incluso el síndrome de estrés postraumático.

Hace poco se publicó en el "New England Journal of Medicine" un artículo de investigación donde participaron algunos miembros de mi departamento y que se hizo por la academia de medicina, donde se demostraba que las mujeres y los hispanos que viven en Nueva York tienen un riesgo mayor de padecer traumas porque tienen otros condicionamientos psicosociales de riesgo: son inmigrantes, tienen barreras lingüísticas, culturales, precariedad en sus situaciones laborales. Un factor importante es la exposición, que es lo que divide a los que están más cerca, menos cerca o indiferente, y el segundo factor importante es saber cuál era la situación de la persona antes de la situación del trauma, es decir, que grado de precariedad tiene en su vida...así cuanto menos apoyo social más riesgo. Todo el conjunto de factores socioeconómicos duplica el riesgo. Los hispanos, a igualdad de condiciones en la exposición, tienen el doble de riesgo, debido precisamente a esos factores psicosociales, que los no hispanos.

Nosotros desde un primer momento intuimos que esa clasificación de riesgo sería importante a la hora planear nuestras intervenciones. 
Periodismo de catástrofes: el 11 de septiembre. Análisis del suceso y experiencias vividas

\section{-La labor de su equipo fue de suma importancia en los primeros momentos, abrieron incluso una línea telefónica para ofrecer asesoramiento psicológico, ¿cuál fue su procedimiento a seguir para actuar?}

- Bueno la línea telefónica estuvo en marcha varias semanas y tuvimos varios miles de llamadas. Hay que pensar en lo que hicimos nosotros en dos etapas: una inicial y otra posterior. En la inicial estuvimos allí en la "zona cero" con otro doctor español no sevillano, el doctor Abad, que estuvo allí organizando las intervenciones del departamento. Ahí fundamentalmente lo que se hizo fue dar mucho apoyo a la gente, organizar y ayudar a las autoridades a que establecieran ritmos de trabajo razonables, profesionalizar más el esfuerzo del rescate facilitando que los voluntarios descansaran, ya que muchos no estaban acostumbrados. Se dio también mucha información educativa y se repartieron más de 15.000 octavillas explicando en qué consiste el estrés, cómo combatirlo...Intervenciones muy breves, aunque por supuesto cuando había casos graves eran evacuados al hospital.

En la etapa posterior nos volcamos principalmente en las poblaciones más afectadas, curiosamente trabajamos en charlas con el personal de los hospitales.

En definitiva hemos aprendido mucho de la importancia de las intervenciones educativas, explicar a la gente qué esperar, cómo esperarlo y cómo combatirlo, y qué medidas de prevención se pueden hacer para cada uno de nosotros y nuestros familiares. También aprendimos que los servicios de psiquiatría tienen que salir a la calle en situaciones de emergencias y de grandes desastres. Si estamos allí viviendo con ellos la situación de rescate es mucho más fácil que la gente se nos acerque, nos pregunte, le escuchemos, porque la gente no suele venir en la proporción que sufren. Con esta actitud lo que hicimos fue desplazar a equipos de psicólogos a muchos lugares. Por ejemplo, cuando las familias empezaron a reunirse días después, nosotros estábamos allí. Hubo una empresa que perdió a 700 de 780 empleados, en esa reunión estuvimos nosotros. También solicitaban nuestra presencia en los cuarteles de bomberos, de manera que en las primeras seis semanas miembros de mi equipo visitaron todos los cuarteles de bomberos de Manhattan. Por supuesto que también estábamos en los congregaciones callejeras donde los familiares portaban las fotos de sus seres queridos con la esperanza de encontrarlos en hospitales. Aquí en la primera semana nosotros lidiábamos con la necesidad de transmitir a estos familiares cuándo ya no se iban a encontrar más supervivientes. Yo recuerdo a una señora hispana que en esos momentos se acercó a mi y me dijo: "mire doctor, esta es la foto de mi hijo que es diabético y lleva ya 7 días sin insulina, ¿usted no cree que eso es muy grave para él?"...cosas durísimas.

Y esta ayuda sólo se puede prestar in situ, hablando con la gente. No hay receta para ello, pero cuando estás entrenado te fluye, aunque a cada persona le llega su momento para aceptar la realidad. 


\section{- ¿Estaban ustedes preparados para una catástrofe de esta magnitud?}

No, ni los hospitales, ni las organizaciones de salud, ni nadie estaba preparado para algo así. Por supuesto todo el mundo teníamos nuestros planes de urgencias donde litúrgicamente se recitaban los pasos a seguir en caso de catástrofes, pero cuando llegó el momento de aplicarlos nos encontramos que los teléfonos no funcionaban, que no había transportes, tuvimos que actuar sobre la base de una improvisación profesionalizada. Los planes eran muy teóricos y una catástrofe de esta magnitud era impensable. Pero nadie paró, a pesar de que las primeras 72 horas nada estaba bajo control, salvo la capacidad de actuación de cada uno, a pesar de lo que dijeran las autoridades. Este hospital, por ejemplo, está estrechamente vinculado con la vida de la ciudad, y por supuesto se volcó la gente donando sangre, la gente se ofrecía voluntaria, los propios médicos se ofrecían voluntarios para ejercer de enfermeros. Y, claro está, intentábamos diariamente coordinar en la medida de lo posible las operaciones.

\section{-¿Cuáles son los síntomas más comunes que han desarrollado los neo- yorquinos tras el 11-S?}

Casi en la misma medida se han desarrollado los síntomas de ansiedad y estrés y la depresión. En la zona más baja de Manhattan el riesgo es mayor, aunque se puede decir que la gente que ha tenido pérdidas probablemente tiene más síntomas de depresión, y la gente que ha estado expuesta al drama tiene más síntomas de ansiedad y estrés.

\section{momentos?}

-¿Qué fue lo que más llegó a afectar a la población durante los primeros

Eso es muy variable, pero quizás la vulnerabilidad de la existencia fuera el primer golpe. La vulnerabilidad y la fragilidad son muy mal procesadas por el cerebro humano. La pérdida de un ser querido que es un acto neurobiológico importante, es uno de los golpes más traumáticos. Otras se vieron muy afectadas por la visión de la gente tirándose desde los últimos pisos....es muy variable.

\section{- ¿En qué medida ha variado usted su rutina de trabajo desde el 11-S?}

Lógicamente en los primeros momentos me absorbió durante el 60-70\%, ahora ha bajado a un $20-25 \%$, y en el futuro irá bajando.

Todavía tenemos un equipo de 15 personas trabajando a jornada completa que trata sobre todo con las familias.

Precisamente, para la celebración del aniversario ya me han llamado para que despliegue a mi equipo; de 12 a 2 mandarlos a los oficios y a la ceremonia de la "zona cero"; a las 3 al Memorial Park, que es donde se encuentran todavía los más de 20.000 restos que aún no han sido identificados, y donde las familias se irán acercando. Va a haber una reanimación de las actividades. 
Ya a partir del segundo año, serán las personas que aún tengan estrés postraumático las que más vayan a solicitar nuestra ayuda.

\section{York?}

- ¿Se deja sentir, un año después, el miedo en la población de Nueva

Digamos que hay una capa de gente alarmista o que tiene la alarma más sensible, que sí tienen miedo, pero yo creo que en la mayoría de las poblaciones lo que hay, más que miedo, es un poco de inseguridad con respecto a la ambigüedad que puede o no pasar, pero no llegaría a la categoría de miedo.

-¿Pueden todavía aparecer secuelas en personas que no hayan desarrollado durante este tiempo ningún síntoma de estrés o depresión?

$\mathrm{Si}$, el trauma diferido. Hay personas que a lo mejor no han desarrollado el síndrome del estrés postraumático, pero un pequeño trauma posterior le puede reactivar, de hecho es algo muy frecuente.

\section{-¿Podríamos decir que se ha recuperado en Nueva York el equilibrio emocional perdido?}

Para la mayoría de los neoyorquinos está a punto, se ve el final de este proceso, por eso es tan importante una celebración modélica del aniversario, es decir, que toda la ciudad se viva a sí misma como triunfadora sobre la destrucción, ese es el símbolo. Aunque a los grupos de riesgo les queda un año más por lo menos.

En este mismo mes de septiembre usted va a presentar un libro que trata, precisamente, de la manera que hay que afrontar este tipo de catástrofes, ¿Qué le ha llevado a escribirlo?

Bueno, en cierto modo esta situación a mí me ha abierto los ojos de la extensión del trauma en la sociedad moderna. Hay mucha gente anónima que los sufre. Los familiares de las víctimas lo han vivido, por ejemplo, de una manera explosiva y pública, pero hay muchos traumas, la violencia doméstica, el maltrato infantil, el abuso sexual, las violaciones, los accidentes de automóviles... que cada año mata a miles de personas dejando a otras miles afectadas de manera traumática. Todo esto me ha hecho reflexionar sobre la importancia del trauma en la vida moderna, y lo que se ha avanzado en los últimos diez o quince años respecto a la centralidad del trauma, los mecanismos neurobiológicos y los tratamientos. Y también me he dado cuenta que, entre lo que se sabe en los laboratorios de los científicos, y lo que se sabe en la calle hay una gran diferencia, y yo he intentado con este libro hacer un pequeño puente para hacer a la gente accesible a los aspectos del trauma. Además es importante preparar a la que gente para que, si les pasa algo de esta magnitud, sepan cómo valorarlo y cómo reaccionar. 
También he tratado con este libro comunicarle a la gente cómo las sociedades competentes lidian en situaciones de estrés. A mi modo de ver la sociedad neoyorquina ha sabido estar a la altura y ha dado la talla, y esos son procesos sociales que no son casuales, ya las sociedades aprenden los mecanismos que hacen que una sociedad responda de una u otra manera.

Este libro que lo he titulado "Psicología para después de una crisis", me ha costado trabajo escribirlo pero me ha gustado mucho hacerlo, porque es una de las lecciones que hemos aprendido de todo lo malo sucedido en Nueva York el 11 de septiembre. 


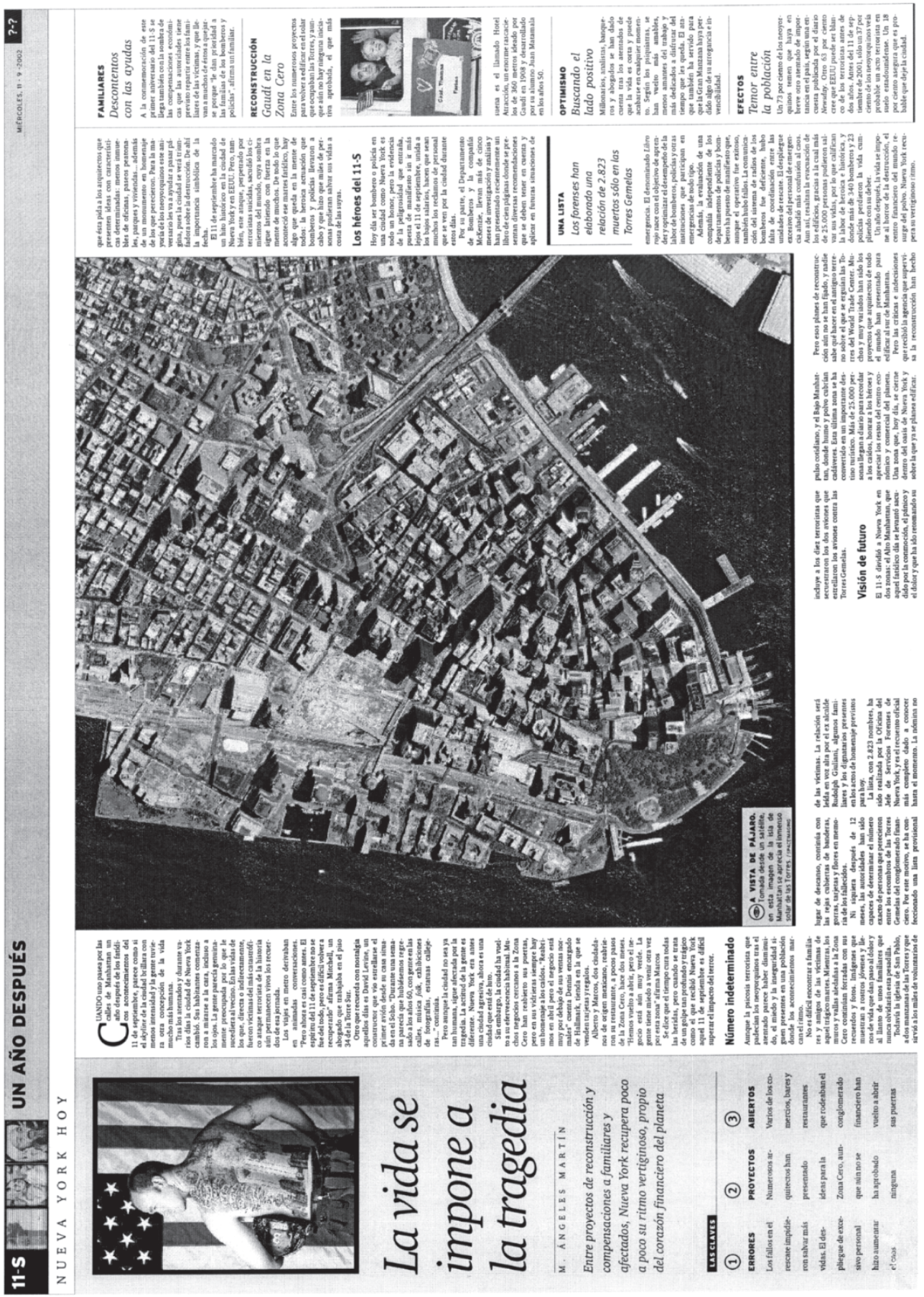

(Recibido el 5-11-2002, aceptado el 12-12-2002) 